Acta vet. scand. $1967,8,390-392$.

Brief communication

\title{
A DEVICE FOR CONTINUOUS ELUATION IN POLY- ACRYLIC AMIDE GEL ELECTROPHORESIS
}

As far back as 1956 Porath (7) called attention to the fact that zone dissemination during eluation is of considerable disadvantage when fractionating mixtures of proteins by means of zone electrophoresis in vertical columns. Various means have been suggested in an effort to master this problem, such as applying particular eluation techniques, e.g., "counter-current eluation" (8) and "counter-flow electrophoresis" (1, 2). Also, special eluation equipment (6) has been designed, and in some cases the entire design of the apparatus has been based on the existence of a permanent eluation device $(3,4,5)$. The eluation

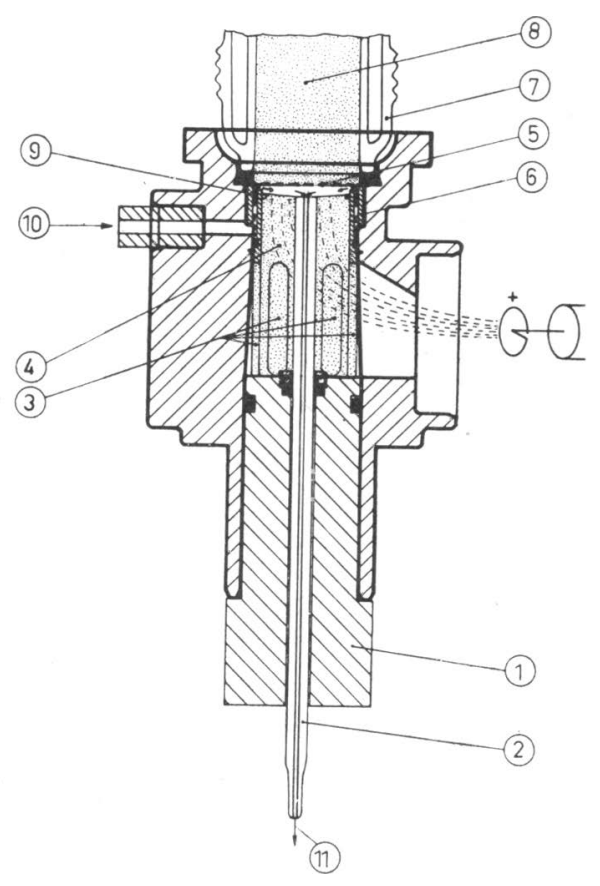

F i g u r e 1. (1) Displaceable special stopper (2) capillary tube (3) slots in stopper (4) polyacrylic amide gel in upper stopper portion (5) polypropylene filter (6) support ring for polypropylene filter (7) separation column of glass, with cooling jacket (8) column packing of polyacrylic amide gel (9) porous Vyon ring (10) inlet for eluation liquid (11) eluate. 
stopper to be described in the present paper should be considered a piece of eluation equipment (cf. illustration and description).

The eluation stopper (1), of a special design, is intended for use in continuous eluation during polyacrylic amide gel electrophoresis. The stopper fits into the circulation couplings of the new LKB type 7900 apparatus, which has been built to suit all hitherto known forms of zone electrophoresis in vertical columns. It is fitted with a displaceable central capillary (2). One-half of the stopper is shaped into a tube with windows (3). By applying a special technique ${ }^{\star}$ ) acrylic amide gel (4) may be poured into the tubular part of the stopper in such a way that a desired $5^{\circ}$ downward slope towards the axis is produced. The stopper's upper gel surface will be at a distance of about $1.5 \mathrm{~mm}$ from the propylene filter (5). This filter forms a support for the polyacrylic amide gel (8) in the separation column (7) which, in electrophoresis of this type, is quite short. The polypropylene filter (5) is attached along its periphery to a support ring (6). A cylindrical ring of porous $\operatorname{Vyon} \circledast$ is inserted between the support ring (6) and the upper portion of the stopper (1) primarily in order to establish a uniform distribution of the liquid flow (as indicated by arrows in the figure) coming from the inlet (10).

With an eluation stopper as described no disturbing membrane or endosmosic effects do occur. However, the zones of substance leaving the separation column, on the other hand, may proceed into the gel mass contained in the stopper. This may be the case if the eluation is carried out too slowly through the eluation space.

Bengt Bergrahm

The Department of Bacteriology and Epizootology, Royal Veterinary College, Stockholm, Sweden.

Roland Harlestam

LKB-Produkter AB,

Stockholm-Bromma, Sweden.

\section{REFERENGES}

1. Eliasson, R., E. Hammarsten \& H. Palmstierna: Separation of nucleic acids and protein by electrophoresis combined with counter flow. Acta chem. scand. 1960, 14, 1212-1214.

*) Cf. instruction manual for LKB apparatus 7900. 
2. Eliasson, R., E. Hammarsten \& T. Lindahl: Separation of polynucleotides and proteins from cell extracts at low temperatures by counter flow electrophoresis. Arch. Biochem. 1962, Suppl. 1, $139-146$.

3. Hochstrasser, H., L. T. Skeggs, K. E. Lentz \& J. R. Kahn: An improved column for preparative electrophoresis. Analyt. Biochem. 1963, 6, 13-26.

4. Hollmén, T. \& E. Kulonen: Separation of the components in collagen by preparative starch-gel electrophoresis. Analyt. Biochem. 1966, 14, 455-466.

5. Jovin, T., A. Chrambach \& M. A. Naughton: An apparatus for preparative temperature - regulated polyacrylamid gel electrophoresis. Analyt. Biochem. 1964, 9, 351-369.

6. Naughton, M. A. \& K. W. Taylor: A method of continuous elution during column electrophoresis. Biochem. J. 1960, 77, 46-47.

7. Porath, J.: Methodological studies of zoneelectrophoresis in vertical columns. Biochim. biophys. Acta 1956, 22, 151-175.

8. Porath, J.: Migration-elution of zones in an electrophoresis column. Nature (Lond.) 1958, 182, 744-745.

(Received September 4, 1967). 